\title{
Entrepreneurial Orientation, Access to Financial Resources and SMEs' Business Performance: The Case of the United Arab Emirates*
}

\author{
Hajer ZARROUK ${ }^{1}$, Mohamed SHERIF ${ }^{2}$, Laura GALLOWAY ${ }^{3}$, Teheni EL GHAK ${ }^{4}$ \\ Received: September 01, 2020 Revised: October 26, 2020 Accepted: November 05, 2020
}

\begin{abstract}
This study investigates how financial resources and entrepreneurial orientation (EO) may influence the performance of small- and mediumsized enterprises (SMEs) in the United Arab Emirates (UAE). Twenty-seven interviews were conducted and evaluated using the method of GABEK ${ }^{\circledR}$ (A GAnzheitliche BEwältigung von Komplexität - holistic processing of complexity). The research demonstrated that access to financial resources has significantly mediated EO's effect on the SMEs' performance. The study found that financial autonomy, enhanced through both personal financing and availability of external finance sources, plays a central role in supporting the EO dimension of autonomy and enhancing the SMEs' performance. In particular, the other EO dimension of risk-taking is stymied by lack of funds with which to take commercial and market opportunities. However, when an innovation strategy is pursued and adopted, access to finance can be facilitated, either through financial institutions or through other governmental funding programs attracting high potential innovators. Furthermore, financial barriers, difficulties accessing bank financing, and legal issues have a detrimental impact on SMEs' growth. The study has implications for policy-makers in the UAE, specifically in terms of sending a signal for lending institutions to consider strategies that provide access to affordable financial services to satisfy SMEs' needs.
\end{abstract}

Keywords: Entrepreneurial Orientation, Financing, Firm Growth, SMEs

JEL Classification Code: K20, L26, M13

\section{Introduction}

\section{*Acknowledgments: \\ [1] The authors acknowledge the financial support from Abu Dhabi Education and Knowledge (ADEK). They thank as well Elarbi Elkaroui and Anas Al Mulla for their contribution in conducting surveys. \\ [2] All authors contributed equally to the article. \\ ${ }^{1}$ First Author and Corresponding Author. [1] Assistant Professor of Finance, Higher Colleges of Technology, Abu Dhabi, UAE [2] University of Tunis El Manar, Faculty of Economic Sciences and Management of Tunis, PS2D, Tunisia [Postal Address: P.O. Box: 41012, Hazza Bin Zayed Street, Al Dhafrah, Abu Dhabi, UAE] Email: hzarrouk@hct.ac.ae \\ 2Professor of Finance, [1] Edinburgh Business School, Heriot-Watt University, Edinburgh, UK [2] KSI University Ras Sadr, Egypt. \\ Email: m.sherif@hw.ac.uk \\ ${ }^{3}$ Professor of Business \& Enterprise, Edinburgh Business School, Heriot-Watt University, Edinburgh, UK. Email: I. galloway@hw.ac.uk ${ }^{4}$ Assistant Professor of Economics, University of Tunis El Manar, Faculty of Economic Sciences and Management of Tunis, LIEI, Tunisia. Email: elghateheni@yahoo.fr}

(C) Copyright: The Author(s)

This is an Open Access article distributed under the terms of the Creative Commons Attribution Non-Commercial License (https://creativecommons.org/licenses/by-nc/4.0/) which permits unrestricted non-commercial use, distribution, and reproduction in any medium, provided the original work is properly cited.
Small- and medium-sized enterprises (SMEs), which play a vital role in every country's economy, are an increasingly pervasive and influential force in the business environment (Qamruzzaman \& Jianguo, 2019; Ključnikov et al., 2020). Globally, they are considered the main engine of job growth, accounted for $45 \%$ of the jobs, controls about $80 \%$ of the formal sector, and contributed $33 \%$ of the GDP on average (OECD, 2017). For the UAE, it represents $94 \%$ of the total number of companies and accounts for $86 \%$ of jobs in the private sector. The UAE environment poses specific challenges to SMEs' development and growth. This indeed is associated with institutional voids characteristic of emerging economies and business model restrictions posed by the Arabian Gulf Cooperation Council (GCC) (Gupta \& Mirchandani, 2018). Although SMEs have had an increasing importance to the economy and individual entrepreneurs, SMEs struggle to access finance. There are indeed differences between the UAE and the GCC environment regarding policy interventions and businesses' ownership structures. In the UAE, the financial sector is still incomplete, and the effect of the socioeconomic environment on SMEs remains unclear. Burdened with the challenges associated with high penalties and side effects of using debt as a finance source, 
it is hard to hedge against the risk facing business activity when both debt and bankruptcy are considered criminal rather than civil issues. Concerning the ownership structures of businesses, most GCC countries require that a country's national has some private firm equity. While in the UAE, $90 \%$ of the population is expatriate (51\% stake by Emirati), implying that any firm created by an expatriate is jointly owned by an Emirati national with the Emirati having the majority of shares.

Prior research has mainly focused on studying the causal relationship between the dimensions-entrepreneurial orientation (EO) - innovativeness, risk-taking, and aggressive competitiveness - and SMEs' performance, but unfortunately they have reached mixed conclusions (Wiklund \& Shepherd, 2005; Avlonitis \& Salavou, 2007; Buli, 2017).

Another important argument that has lately been given much attention is related to the vital role of access to finance as a mediator in the relationship between EO and SME performance (Lumpkin \& Dess, 1996; Wiklund \& Shepherd, 2005; Covin \& Lumpkin, 2011; Ghimire \& Abo, 2013). In this context, there is little consensus regarding the explanations of the mediator effect of access to finance in the relationship between EO and SME performance (Beck et al., 2008).

This study complements existing studies and contributes additional findings to the analysis by focusing on the UAE. It helps fills the gap in the moderator effect literature and whether EO represented by four main dimensions autonomy, innovativeness, risk-taking, and aggressive competitiveness - would increase access to finance, which in turn increases SMEs' performance.

The rest of the study is organized as follows. Section 2 presents a detailed literature review. The research methodology and data are discussed in Section 3. Section 4 shows the empirical results. Section 5 concludes, considering the significance of the key findings and outlining future research avenues.

\section{Review of Theory and Literature}

\subsection{Review of Theory}

Now well established in entrepreneurship research and scholarship, the theory of entrepreneurial orientation (EO) has been refined over time. The most important contribution in this field was made by Miller (1983). She introduced the idea, explaining that an entrepreneurial firm is one that "engages in product market innovation, undertakes somewhat risky ventures, and is first to come up with "proactive" innovations, beating competitors to the punch' (Miller 1983, p. 771). Lumpkin and Dess (1996, p. 139-140) added to these three criteria 'competitive aggressiveness' and 'autonomous action'. Cumulatively, five key dimensions are required within firms for entrepreneurship (Covin \& Lumpkin, 2011;
Covin \& Wales, 2012) $)^{1}$. Some econometric analyses found correlations between the EO dimensions, suggesting they co-vary with each other (Ferreira et al., 2011). Other studies found that the EO dimensions may vary independently (Pett \& Wolff, 2016). Either way, it seems established that EO dimensions are not all required in equal measure all of the time for a firm to be entrepreneurial. However, there is a relationship between EO and performance measured as business growth (Vu, 2020). EO theory was initially applied to strategic orientation in large firms. However, the studies are increasingly applying EO theory in the small firm's context. For example, Steyaert and Katz (2004) argued that financial sustainability and social objectives necessitate the generation of sufficient profits to invest in business activities and to drive forward social change. To do so, entrepreneurs should craft a balance between acquiring resources to build and maintain competitive advantage and using resources to engage with their key stakeholder. In the context of funding in SMEs, the resource-based theory assumes that capital is a crucial competitive advantage source when finance sources are dearth.

\subsection{Literature on Entrepreneurial Orientation, Access to Finance and Firm Performance}

The issue of how EO impacts on the performance of SMEs has been the basis of intense debate. For example, Avlonitis and Salavou (2007) claimed significant overlapping and interconnection between entrepreneurial firms, profitability, growth, firm performance, and innovation. In this line, Zampetakis et al. (2011) demonstrated that firms with better EO scores maintain higher governance effectiveness and performance levels. Similarly, Rauch and Frese (2009) found that EO explained $24 \%$ of firm performance. Elsewhere, Western-based studies (Rauch \& Frese, 2009; Zampetakis et al., 2011) reported that EO is mostly associated with business performance as a primary dependent variable. Other studies, such as Fatoki (2012), claimed that EO-firm performance nexus is more complicated than has a negative impact on firm performance.

Furthermore, Sherif et al. (2019) investigated the relationship between SMEs'performance and EO dimensions, and they found that autonomy is the only EO dimension that has a positive correlation with SMEs' performance. Autonomy was further found as a capstone dimension, in line with the hypothesis that if a firm cannot operate with autonomy, the other dimensions are limited in terms of their achievability. For example, the lack of autonomous ownership amongst expatriate founders can stymie risktaking, the ability to be proactive, and develop innovation (which inherently involves risk, of course). Avlonitis and Salavou (2007) found an insignificant relationship between EO and performance. Scholars like Rauch and Frese (2009), Mukiri (2011), and Rosenbusch et al. (2013) argued that 
any positive relationship between $\mathrm{EO}$ and performance does not hold homogeneously for all contexts and there are other external and internal variables - such as dynamics of the environment, access to finance, munificence, complexity, and various organizational factors - mediate it. According to the World Bank (2011), the aggregate economic performance is a factor improved by increasing access to financial resources and capital. In another key study, Haung et al. (2011) claimed that entrepreneurs associated with higher risk-taking levels are more willing to accept considerable risk when asking for and access external financial capital.

Similarly, Ghimire and Abo (2013) argued that the decisions made on capital sources and SMEs' access to debt are subject to the strategic abilities of firms relying on entrepreneurial characteristics. Likewise, entrepreneurial skills enhance better and adequate access to financial resources (Mohammed \& Obeleagu-nzelibe, 2014). In this line, Ayyagari et al. (2011) found that bank financing has a significant impact on firms' growth; and such growth relies mainly on alternative financing channels. They also argued that adequate access to finance has a significant positive impact on agricultural crop yields. Furthermore, Hussain et al. (2006) indicated that access to finance is considered a key driving factor in enabling economic environment and growth.

Beyond this, it is broadly hypothesized that $\mathrm{EO}$ requires considerable financial resources to be successful (Covin \& Lumpkin, 2011). This is consistent with a few previous studies that have explored EO beyond the developing economy context. For example, Mukiri (2011) found that firms with effective EO dimensions are more prone to focus attention on new and emerging opportunities for obtaining capital. In this line, Haung et al. (2011) argued that firms characterized by risk-taking behavior often make large financial resource commitments. Similarly, Mohammed and Obeleagunzelibe (2014) examined 250 employers and employees from SMEs and found that entrepreneurial skills enhance better financial resources access.

Overall, SMEs are known to be financially more constrained; and are less likely to have access to formal finance (long-term loans) than those associated with large firms (Beck et al., 2006). In the same order of ideas, numerous surveys conducted by the World Bank claimed that SMEs often consider SMEs' access to finance as one of the key barriers preventing them from being well-functioning in developed and developing countries. Elsewhere, a strand of research (Cuevas et al., 1993; Ayyagari et al., 2005) argued that the adequate access to finance is a significant determinant of the development and growth of African enterprises. Findings by Zarrouk et al. (2017) revealed a highly significant causal relationship between financial development and real economic activity where access to financial resources and the ability to finance new projects seem to stimulate economic growth in the UAE. In the same vein, Butler and Cornaggia (2009), and Levine and Warusawitharana (2014) found that providing credit to SMEs stimulates and enhances the economic growth; more credit leads to more entrepreneurship in the forms of firm formation and growth. In a survey conducted by the IMF (2019), the SME access to financing in the Middle East and Central Asia is the main impediment compared with other countries at similar economic development levels. On the same order of ideas, Sadiq (2016) attributed SMEs' failure to underestimating the power of having adequate financing and inadequacy control of net working capital.

Despite the compelling role of SMEs to the country's socioeconomic advancement, it has become ambitious for them to get access to a short-long term and flexible credit sources. Several justifications have been considered to explain the absence of access to credit and finance by SMEs such as high-risk associated with SME lending; information asymmetry arising from SME lending; and the high administrative transaction costs involved in SME financing and weak institutional and legal structures (Cuevas et al., 1993; Beck et al., 2006). Equipped with the above analysis, several themes emerge. First, in the UAE context, EO dimensions are affected by business models' structural constraints that prohibit autonomy in many firms. Second, financial factors and specifically limited access to financial products influence the EO dimensions and business performance and growth in the context-specific perspectives. Here, Cuevas et al. (1993) indicated that access bank lending is considered one of the fundamental problems facing SMEs due to SMEs' inability to offer good quality collateral as a pledge to secure loans. According to Cuevas et al. (1993), the absence of fixed assets (landed properties and building) for SMEs stopping them from attaining short term credit from banks. In another study, Kauffmann (2005) argued that firms should use other financing sources, such as leasing, factoring, and the use of brand names to reduce their failure risks.

\section{Methodology and Results}

Two key themes have been explored and reported in this research: first, the experiences of enterprise or entrepreneur in circumstances of autonomy, innovativeness, risk-taking, and aggressive competitiveness; and second, the effectiveness of finance resource interventions in enhancing firm performance - and means by which capital is made available in particular - to help to enhance different dimensions of EO.

With a dearth of previous research that engages with these themes, this study took an exploratory approach. In particular, the opinion of those who engage with the issues central to enterprise and business ownership - running a small business in the UAE. Applying a qualitative methodology, in-depth interviews were conducted with 27 business owners representing 24 firms. Business ownership is structured 
on a 51:49 shareholding basis for Emirati and expatriates, respectively. It is worth noting that all businesses in our study are operating outside the 'free zone' business activity.

Data were collected by eliciting key informants' testimonies via semi-structured interviews, designed to encourage narratives from the points of view of participants so that, within the stories related, themes meritorious of consideration and analysis might emerge (Salkind \& Rainwater, 2006). GABEK toolset (Zelger \& Oberprantacher, 2002) was used to compile key informants obtained from entrepreneurs and expatriates engaged in these agendas. Interviews were conducted at informants' places of work or by phone. They were all recorded and transcribed verbatim, and analyzed with the aid of the GABEK technique toolset (including the software implementation WinRelan)2.

Using the GABEK technique: (i) first, text units were defined and interview data were divide into closed statements; (ii) text units are then coded on a keywordbasis; 3-9 keywords are chosen, which are considered suitable to represent the respective text unit, and the causal relationships concluded from the interviews are mapped; and (iii) the coded keywords are then automatically translated to undirected networks (association graphs) and directed networks (causal net graphs).

\subsection{Insights from Key Informants}

Overall, the research findings refer to three emerging themes; the enterprise start-up stage, business growth procedures, and business expansion and development. Through different growth stages of business, 'SMEs' financing' is investigated to explore firm business' owner perceptions of relevant entrepreneurial dimensions; and whether the access to finance can affect entrepreneurial dimensions, namely, innovation, risk-taking, and autonomy.

\subsection{Enterprise Start-up Stage}

This section analyzes which entrepreneurial expressions and financial access the interviewees associate with the selected key business growth term throughout their narratives. The analysis includes how strong these associations are (numbers of connecting lines, reflect the appearances in the interviews) and how often such expressions are positively $(+)$ or negatively $(-)$ perceived by the interviewees.

Figure 1 shows the overlapping associated with the start-up businesses stage and all relevant connections and networks obtained from the interviews. As shown in Figure 1 , the number of text units has appeared in the middle of the connecting lines. Second, causalities to the selected key business growth terms, as perceived by the interviewees, identify the role of access to finance in improving SMEs' performance. To conclude, businesses' owners require sufficient and essential financial capital and necessary products to start a business. 'Autonomy' and auto-financing are intercorrelated factors, meaning that entrepreneurs should invest new working capital to be autonomic when establishing a new business.

Access to finance is one of the main restrictions for establishing new businesses. On the one hand, entrepreneurs are scared of applying for a bank loan to start-up a new business. There was also some suggestion of risk-aversion, which interestingly, was expressed by Emiratis in this study rather than expatriates. The following quotations are illustrative:

"I do not want to take a loan from banks because I am not sure that I will have profit to pay back my loan. ... Yes, I am too cautious, so I do not want to take loans. If I have money, I invest, and if I do not have I will not invest! . I invest in what I have, but I am not ready to get a loan from anybody to do business. ... I do not like debt' (Interviewee A, decoration).

'In general, I do not like to take risks. . . I have heard a lot about the issues of bank loans, the cases and legal issues that they have had. Consequently, I think if I have to deal with banks, I would be very cautious. I ask myself the following questions: 'Are you going to be committed, have self-control, do you have another account or a way to repay your loan if you cannot do that through your business?' I think these things are essential before taking the decision of borrowing from banks?' (Interviewee T, Engineering services).

Interviewee T's testimony refers directly to the fear of failure associated with risk. While, in theory, poor outcomes of risk seem most serious for expatriates since their visas rely on good credit, the potential severity of penalties for Emiratis also appears to be a significant deterrent. For financial institutions, as seen in Figure 2 (red and black arrows), the start-up business faces some difficulties in opening a bank account or benefitting from the formal financial services provided by those institutions. Overall, the UAE entrepreneurs are facing significant restrictions in securing loans and having access to finance when there is a dearth in sources of finance. Even the determinants of finance such as interest rate, fees, and commissions charged to the borrowers are factors of importance to continuing operating business (Claessens, 2006). Figure 2 shows the determinants associated with the business stage. The arrow sign indicates the direction of the causality relationships where each determinant is positively influencing the input of the rest of the dominations. The two-way arrow implies a mutual benefit across access-to-finance determinants. Hence, the analysis concludes that access to finance and autonomy are interconnected and positively impact business performance. This is in line with the Khalifa Funds requirements. Summary comments from interviews testify the intercorrelation between the requirements of Khalifa Fund loan' and 'auto-financing': 


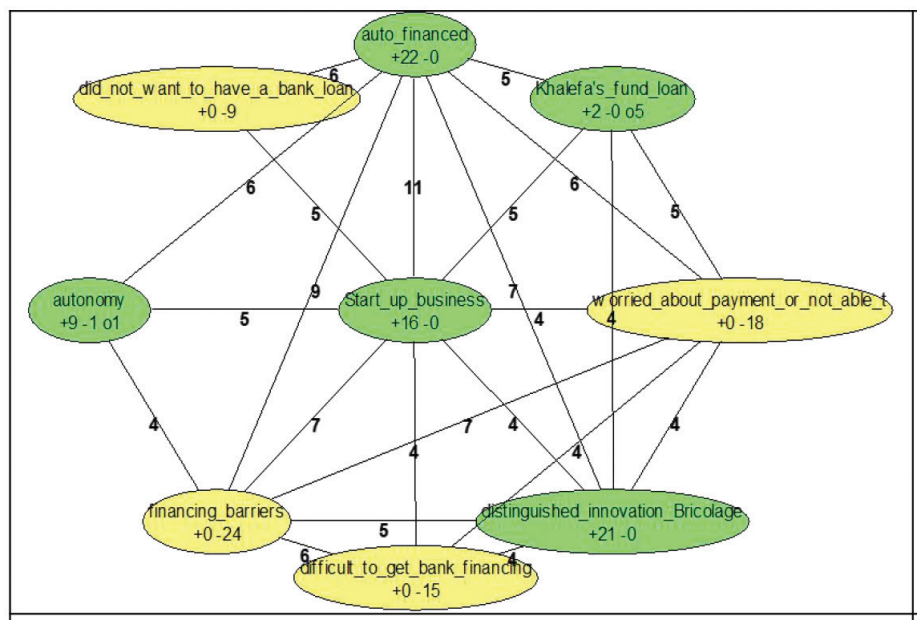

Figure 1: Start-up Business

Notes: Number on lines $=$ number of appearances; $+=$ positive and $-=$ negative evaluation.

"When I start my project, the available amount was zero; I borrowed a lot, in order to deal with H.H. Fund, 72,000 I had to deal with. I collected a lot from my relatives, I was not aware of a point that we must have such amount in order to deal with H.H Shaikh' khalifa's fund... When they feel that the project started and get profits, they get back their debts, and this is their right to get it back". (Interviewee, F, Restaurant).

"For opening an account, the bank refuses my request as I have an office in a business center... Even for $L / C$, you need to maintain a 100 cash margin, and in this case, what is the benefit? So really very Tough nowadays". (Interviewee M, Medical Supplier).

"I advise anyone willing to do business to make a complete study including all points before starting as barriers might be hidden or very specific. The financial barrier is a major one, I believe." (Interviewee M, Media, and Advertising).

This implies that family and friends are considered a key financing source when initially starting a new business due to the dearth of other alternative sources of finance. It is worth noting from interviews that none of the entrepreneurs were aware of equity crowdfunding financing, venture capital, or any other sources of private capital- recently emerged in the UAE economy.

\subsection{Business Growth Stage}

Exemplified by comments obtained from interviews, Figure 3 shows the risk and legal aspects that are negatively impacted on business performance.

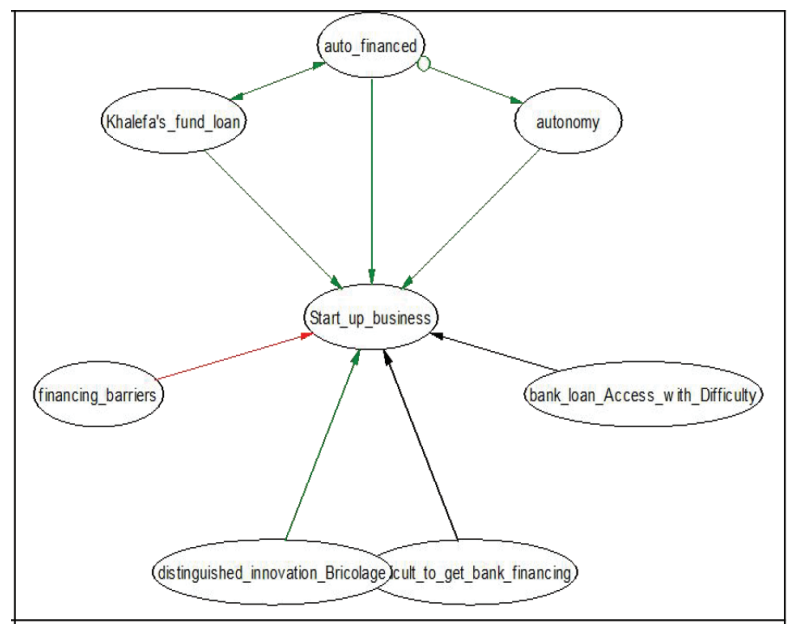

Figure 2: Causality Relationship - Start-up Business

Red: negative impact; Green: positive impact; Black: ambivalent impact on business performance.
Entrepreneurship requires risk-taking, and in small firms, this aspect requires strong leadership to pursue risky actions to continue business growth and ensure the longevity of the business ( $\mathrm{Vu}, 2020)$. From the expatriate point of view, independent business ownership outside of the limited free zones is not possible. In fact, an expatriate cannot even be a majority shareholder. This ownership structure for expatriates is likely to inhibit their autonomy, thereby inhibiting their ability to take strategic - including risky - decisions. From interviews, business growth was correlated with innovation. It is defined as technological innovation or product-market innovation, the former comprising technological advance through R\&D, the latter comprising new market application of products (Lumpkin \& Dess, 1996).

Focusing on the importance of innovation to small firms (Hoang \& Ngoc, 2019; Lee \& Xuan, 2019; Lestari et al., 2020), Figure 3 shows the interconnection between distinguished innovation and business growth. The informants emphasized that providing high-quality products and services that positively impact the growth of their business. They explain it thus:

".. Either to innovate or not survive”. Innovation is a way to go, to be an owner, to take a business model to be the creator of a product." (Interviewee M, Developing Software).

Some other Emirati owners highlighted the correlation between securing and facilitating finance sources and providing 'Technology_Innovative_Product.'

"It is easy to get financing from a bank or local funding agencies. The government can also provide grants.... 
financing support is available from funding agencies; we get a training program from the Khalifa Fund. Yes, I get involved in the Ibtikari program to get training... I am also a member of the Dubai program SME, where we get involved with their guidance, with their support and attending their exhibitions, and we enjoy all of their services, reducing the running cost of not to have a renting and a lot of modules that you can start your business as UAE entrepreneur with a minimum of cost." (Interviewee M, Developing Software).

"I don't think I will take a loan from banks because I am not quite sure that I will have a profit or not to pay back my loan... I am too cautious not to take loans. "(Interviewee F, Decorator).

Figure 4 exhibits the significant variables that negatively impacted on the access to finance and business growth, namely: financing barriers, the difficulties to get bank financing and legal and regulatory issues. Summary comments testify:

"Corporate Banks in UAE will not give loans unless they go in a deep investigation and prove that this company, at least for the last three years they are doing business. I have visited many banks... I can tell you, if you are not doing business for almost 10 million a year, nobody will consider your request. NO ONE! I tried, almost in 6-7 banks." (Interviewee M, Medical Supplier).

Overall, the findings imply a weak relationship between banking institutions and SMEs with the lack of finance dialogue. Other important factors that impacting the business development are: having enough auto-financing, getting support from Khalifa Fund, and innovative products.

\subsection{Expanding Business}

While some firms comprise wholly Emirati ownership, and there are 'freezones', in which independent expatriate businesses may operate, by far the most common business structure is firms co-owned by an Emirati and expatriate. SMEs' access to financing, legal constraints, and lack of autonomy are considered the main factors that hinder the ability of Expat owner to secure bank financing. While Figure 5 shows that 'autonomy' dimension of EO is considered the most influential factor impacting on firm performance, this is exemplified by:

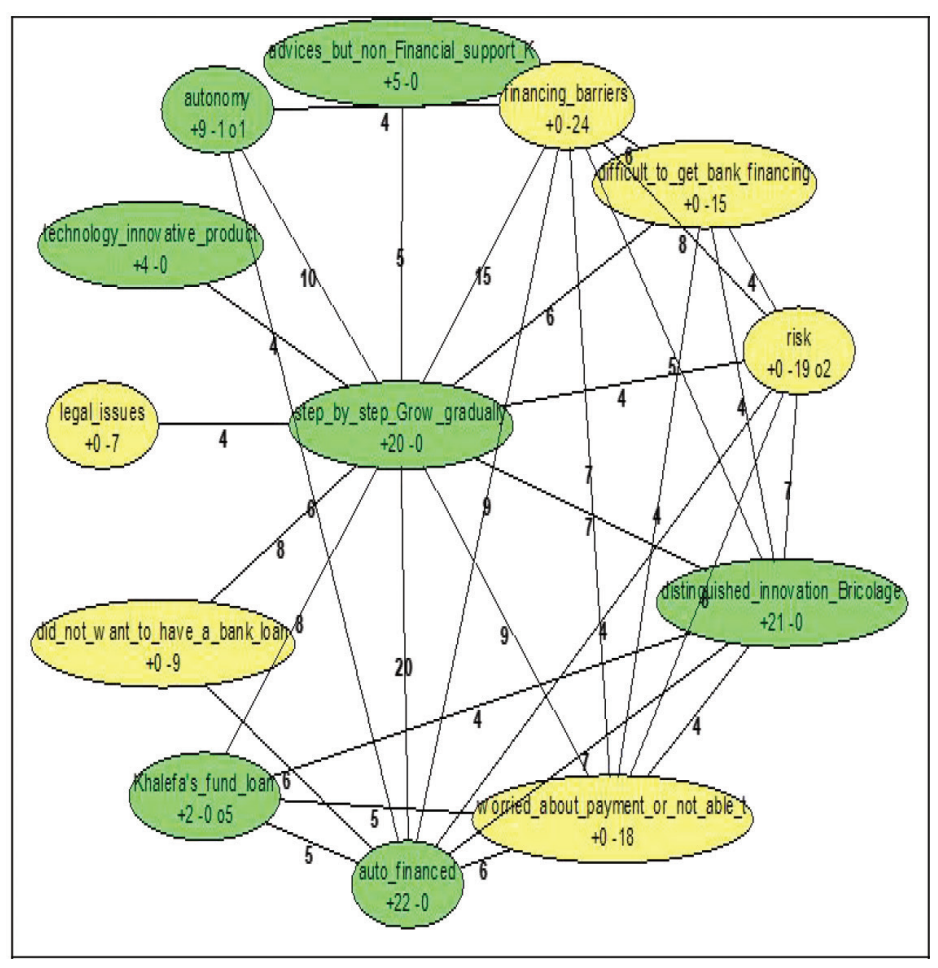

Figure 3: Business growth Stage

Notes: Number on lines $=$ number of appearances; $+=$ positive and $-=$ negative evaluation.

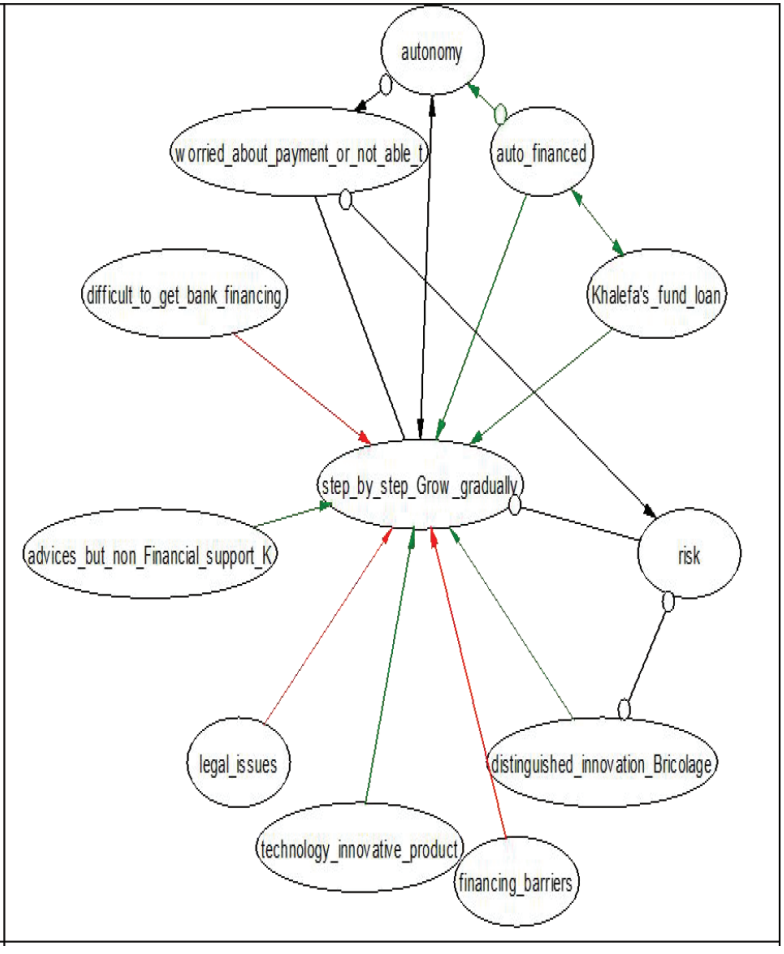

Figure 4: Causality Relationship - Growth Stage

Red: negative impact; Green: positive impact; Black: ambivalent impact on business performance. 


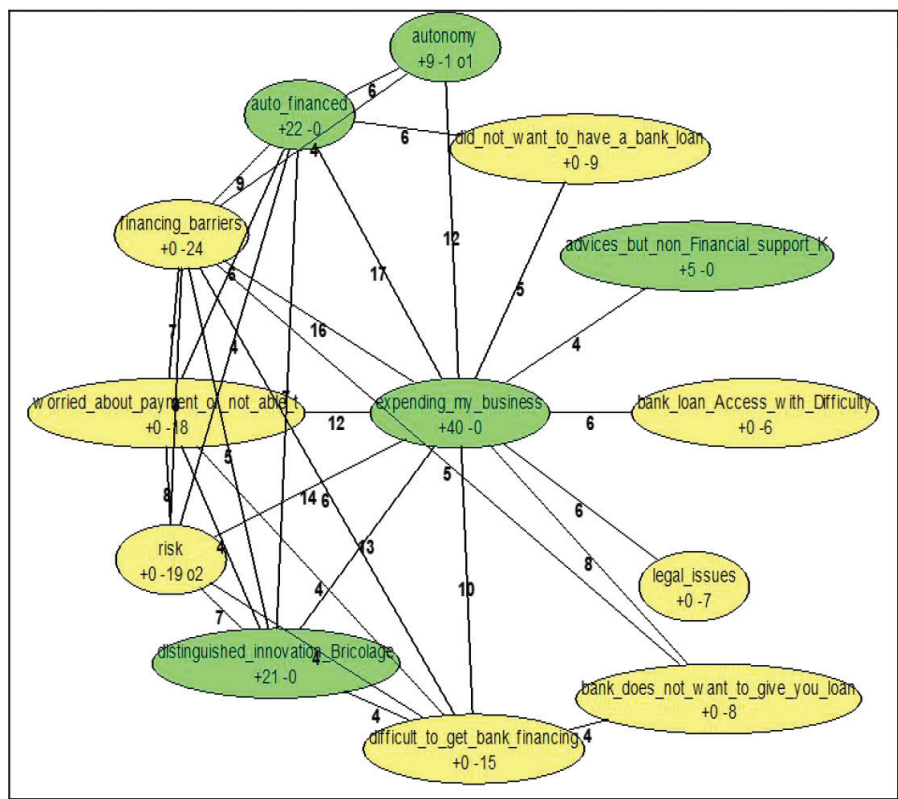

Figure 5: Business Expansion

Notes: Number on lines $=$ number of appearances; $+=$ positive and $-=$ negative evaluation.

"The loan will be au benefit of the company, generating more profit, but the responsible is the Emirati owner. .... I presented that to him, but he did not show any interest ... and I did not get an advantage of this opportunity. " (Interviewee M, Medical Supplier).

Figure 6 reports the causality relationship associated with business expansion; and indicates that financial constraint has mainly causal relationship with business growth at an advanced level.

\section{Discussion}

This study proposes that UAE is a unique context to explore EO since it diverges from the Western business world in two important ways. First, it is an emerging rather than a developed economy, though (unlike some other emerging economies) it has considerable wealth and global reach. Second, as a consequence of policy ambitions to diversify the economy and capacity-building skills and knowledge amongst the local indigenous population, in-migration and co-ownership in the business sector have been encouraged, a business model somewhat unique to that part of the world.

From an emerging economy perspective, data in this study finds that firms engaged with bricolage rather than innovation faced barriers preventing them from exercising other entrepreneurship dimensions. These barriers comprise institutional voids in the form of an underdeveloped finance

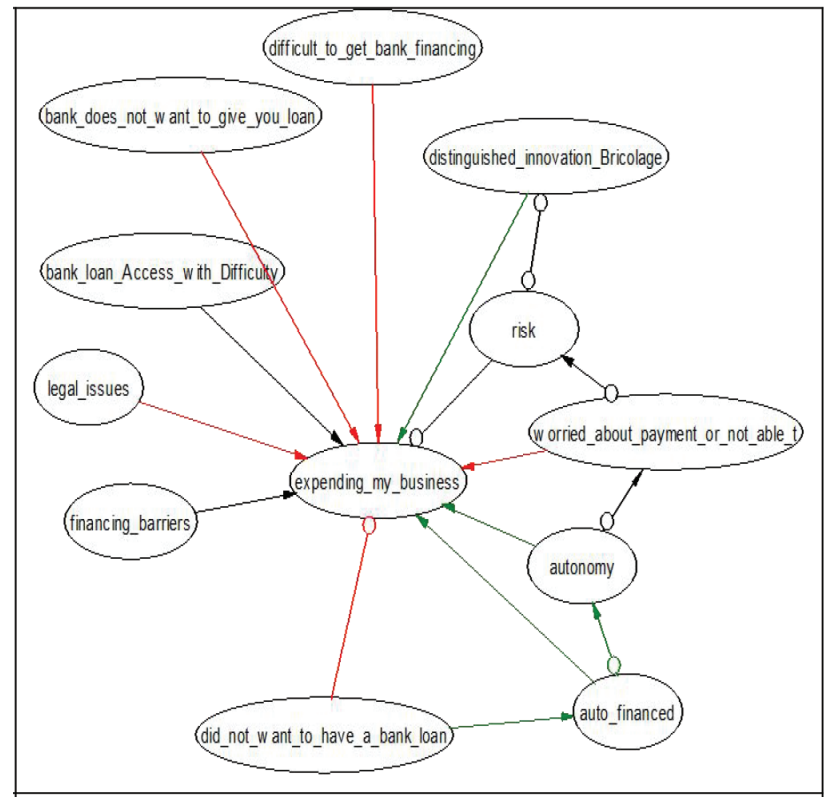

Figure 6: Causality Relationship - Business Expansion

Red: negative impact; Green: positive impact; Black: ambivalent impact on business performance.

system, an incomplete regulatory environment for risk in terms of insurance and business failure, and some evidence - perhaps now improved by being online - of cumbersome bureaucracy for small firms. Further, the institutional requirements of the 51:49 ownership structure render autonomy precarious at best, which has knock-on implications in terms of further limiting the ability to take risks and, indeed, any strategic decision on any EO dimensions.

This study has showed that autonomy is a critical element of entrepreneurial capacity during all stages of business cycles. Without autonomy the decision and actions required for entrepreneurship cannot happen. This is in line with the previous studies (Sherif et al., 2019; Zarrouk et al., 2020) that found clear evidence that autonomy is a key determinant of EO and firm performance. However, the co-ownership structure is not crystal clear, and the free zones have mitigated the autonomy problem. Despite the increasing impact of autonomy on firm performance when using 51:49 ownership structure, the expansion of more 'freezone' business activity has motivated innovation and entrepreneurship in the UAE.

Regarding different stages of the business cycle, the results, overall, indicate that the most commonly reported issue impacting the ability and capacity to take risks and so innovate in business, that is to act entrepreneurially, was lack of finance availability. Evidence from this study supports Schammo (2019) assertions, amongst others, that support needs for SMEs to secure external finance due to the lack of awareness on different other sources of finance. 
"No interviewee mentions that there is alternative non-bank financing, even when asked if they have any access to nonbank funding the answer was always no". Authors.

This is justified as SME businesses consider the bank as the first port of call for financing and have insufficient information on different funding sources. This is in line with Schammo (2019), who pointed out the role of matchmaking in the SME funding space, where businesses are funded by different lenders who were having lending appetites or dealing with a certain level of risk. This support the contention, therefore, that intervention to prompt and support enterprise in low-resource contexts is a question of some importance. And pertinently, this study raise the question of what credit product design choices and screening mechanisms would be appropriate for microcredit providers seeking to support the growing number of start-up businesses.

\section{Conclusion}

This paper examined whether access to finance can be a mediator in the relationship between EO and business performance. The analysis contributes to the scientific literature in EO and SMEs financing in the UAE rarely discussed, and not much progress has been made in this area.

The findings reveal that the resources of finance have a positive impact on autonomy dimension of EO and ultimately improve the business performance. The findings also indicate that when a technological innovation strategy is adopted, access to finance is facilitated, either through financial institutions or through other governmental funding programs.

The most obvious limitation in this study that could be addressed in future research is the small number of interviews confined only one state in the UAE. Hence, it is rather biased to assume that an individual response is a reliable and valid indicator to represent the whole population and stopped us from performing the final step of the methodology: a Gestalten-tree. The replication of this study in different regions of UAE would enable better generalizability of the findings, and have better responses to improving the findings. Also, future work should ponder other factors such as business networking, economic factors and competition that might have an impact on business performance.

\section{References}

Avlonitis, G. J., \& Salavou, H. E. (2007). Entrepreneurial Orientation of SMEs, Product Innovativeness, and Performance. Journal of Business Research, 60(5), 566-575.

Ayyagari, M., Demirgüç-Kunt, A., \& Maksimovic, V. (2005). How Important are Financing Constraints? The Role of Finance in the Business Environment. World Bank Mimeo.
Ayyagari, M., Demirgüç-Kunt, A., \& Maksimovic, V. (2011). Small vs. Young Firms Across the World - Contribution to Employment, Job Creation, and Growth. Policy Research Working Paper 5631. The World Bank Development Research Group.

Beck, T., Demirguc-Kunt, A., \& Maksimovic, V. (2008). Financing Patterns Around the World: Are Small Firms Different? Journal of Financial Economics, 89(3), 467-487.

Beck, T., Demirguc-Kunt, A., Laeven, L., \& Maksimovic, V. (2006). The Determinants of Financing Obstacles. Journal of International Money and Finance, 25(6), 932-952.

Buli, B. M. (2017). Entrepreneurial Orientation, Market Orientation and Performance of SMEs in the Manufacturing Industry: Evidence from Ethiopian Enterprises. Management Research Review, 40(3), 292-309.

Butler, A., \& Cornaggia, J. (2009). Does Access to External Finance Improve Productivity? Evidence from a Natural Experiment. Journal of Financial Economics, 99(1), 184-203.

Claessens, S. (2006). Access to Financial Services: a Review of the Issues and Public Policy Objectives. The World Bank Research Observer, 21(2), 207-240.

Covin, J. G., \& Lumpkin, G. T. (2011). Entrepreneurial Orientation Theory and Research: Reflections on a Needed Construct. Entry Theory and Practice, 35(5), 855-872.

Covin, J. G., \& Wales, W. J. (2012). The Measurement of Entrepreneurial Orientation. Entrepreneurship Theory and Practice, 36(4), 677-702.

Fatoki, O. (2012). The Impact of Entrepreneurial Orientation on Access to Debt Finance and Performance of Small and Medium Enterprises in South Africa. Journal Social Science, 32(2), 121131.

Ferreira, J. J., Azevedo, S. G., \& Ortiz, R. F. (2011). Contribution of Resource-based View and Entrepreneurial Orientation on Small Firm Growth. Cuadernos de Gestión, 11(1), 95-116.

Ghimire, B., \& Abo, R. (2013). An Empirical Investigation of Ivorian SMEs Access to Bank Finance: Constraining Factors at Demand-level. Journal of Finance and Investment Analysis, 2(4), 29-55.

Gupta, N., \& Mirchandani, A. (2018). Investigating Entrepreneurial Success Factors of Women-owned SMEs in UAE. Management Decision, 56(1), 219-232.

Haung, K. P., Wang, K. U., Chen, K. H., \& Yien, J. M. (2011). Revealing the Effects of Entrepreneurial Orientation on Firm Performance. A Conceptual Approach. Journal of Applied Sciences, 11(6), 3049-3052.

Hoang, C. C., \& Ngoc, B. H. (2019). The Relationship between Innovation Capability and Firm's Performance in Electronic Companies, Vietnam. Journal of Asian Finance, Economics and Business, 6(3), 295-304. https://doi.org/10.13106/jafeb.2019. vol6.no3.295.

Hussain, J., Millman, C., \& Matlay, H. (2006). SME Financing in the UK and in China: a Comparative Perspective. Journal of Small Business and Enterprise Development, 13(4), 584-599. 
IMF. (2019). Financial Inclusion of Small and Medium-Sized Enterprises in the Middle East and Central Asia. IMF working paper No. 19/02.

Kauffmann, C. (2005). Financing SMEs in Africa. OECD Development Centre International. Journal of Trade, Economics and Finance, 7(2), 38-43.

Ključnikov, A., Civelek, M., Çera, G., Mezuláník, J., \& Maňák, R. (2020). Differences in Entrepreneurial Orientation (EO) of SMEs in the International Context: Evidence from the Czech Republic and Turkey. Engineering Economics, 31(3), 345-357.

Lee, J. W., \& Xuan, Y. (2019). Effects of Technology and Innovation Management and Total Factor Productivity on the Economic Growth of China. Journal of Asian Finance, Economics and Business, 6(2), 63-73. https://doi.org/10.13106/jafeb.2019. vol6.no2.63

Lestari, S. D, Leon, F. M., Widyastuti, S., Brabo, N. A., \& Putra, A. H. P. K. (2020). Antecedents and Consequences of Innovation and Business Strategy on Performance and Competitive Advantage of SMEs. Journal of Asian Finance, Economics and Business, 7(6), 365-378. https://doi.org/10.13106/jafeb.2020. vol7.no6.365

Levine, O., \& Warasawitharana, M. (2014). Finance and Productivity Growth: Firm-level Evidence. Finance and Economics DP, Federal Reserve Board, No. 2014-17.

Lumpkin, G. T., \& Dess G. G. (1996). Clarifying the Entrepreneurial Orientation Construct and Linking it to Performance. Academy of Management Review, 21(1), 135-172.

Miles, M. B., \& Huberman, A. M. (1994). Qualitative data analysis: An expanded sourcebook. Thousand Oaks, CA: Sage Publications.

Miller, D. (1983). The Correlates of Entrepreneurship in three Types of Firms. Management Science, 29(7), 770 - 791.

Mohammed, U. D., \& Obeleagu-nzelibe, C. G. (2014). Entrepreneurial Skills and Profitability of Small and Medium Enterprises (SMEs): Resource Acquisition Strategies for New Ventures in Nigeria. 25th International Business Research Conference (1-21). Cape Town.

Mukiri, M. G. (2011). Determinants of Access to Bank Credit by Micro and Small Enterprises in Kenya.www.growinginclusivemarkets. org/media/publications/determinants_of_access_to_bank_ credit_by_micro_and_small_enterprises_in_kenya.pdf.

OECD. (2017). Enhancing the Contributions of SMEs in a Global and Digitalised Economy. Paris: OECD.

Pett, T., \& Wolff, J. A. (2016). Entrepreneurial Orientation and Learning in High and Low Performing SMEs. Journal of Small Business Strategy, 26(2), 71-86.

Qamruzzaman, M., \& Jianguo, W. (2019). SME Financing Innovation and SME Development in Bangladesh: An Application of ARDL. Journal of Small Business \& Entrepreneurship, 31(6), 521-545.

Rauch, A., \& Frese, M. (2009). Psychological Approaches to Entrepreneurial Success: a General Model and an Overview of Findings. In: Cooper, C.L., \& I. T. Robertson(Ed.), International
Review of Industrial and Organisational Psychology. Chichester, UK: Wiley. 101-142.

Rosenbusch, N., Rauch, A., \& Bausch, A. (2013). The Mediating Role of Entrepreneurial Orientation in the Task EnvironmentPerformance Relationship: A Meta-Analysis', Journal of Management, 39(3), 633-59.

Sadiq, R. (2016). Impact of Working Capital Management on Small and Medium Enterprises' Performance in Nigeria. Arabian Journal of Business and Management Review, 7(1), 1-5.

Salkind, N. J., \& Rainwater, T. (2006). Exploring research. Upper Saddle River, NJ: Pearson Prentice Hall.

Schammo, P. (2019). Undisruption' in the SME Funding Market: Information Sharing, Finance Platforms and the UK bank Referral Scheme. European Business Organization Law Review, 20(1), 29-53.

Sherif, M., Galloway, L., \& Zarrouk, H. (2019). Performance and Entrepreneurial Orientation in SMEs: the Case of Abu Dhabi. Int. J. Accounting, Auditing and Performance Evaluation, 15(3), 241-261.

Steyaert, C., \& Katz, J. (2004). Reclaiming the Space of Entrepreneurship in Society: Geographical, Discursive and Social Dimensions. Entrepreneurship \& Regional Development, 16(3), 179-96.

Vu, H. M. (2020). A Review of Dynamic Capabilities, Innovation Capabilities, Entrepreneurial Capabilities and Their Consequences. Journal of Asian Finance, Economics and Business 7(8), 485-494. https://doi.org/10.13106/jafeb.2020. vol7.no8.485

Wiklund, J., \& Shepherd, D. (2005). Entrepreneurial Orientation and Small Business Performance: A Configurational Approach. Journal of Business Venturing, 20(1), 71-89.

Zampetakis, L. A., Vekini, M., \& Moustakis, V. (2011). Entrepreneurial Orientation, Access to Financial Resources, and Product Performance in the Greek Commercial TV Industry. The Service Industries Journal, 31(6), 897-910.

Zarrouk, H., El Ghak, T., \& Abu Al Haija, E. (2017). Financial development, Islamic finance and economic growth: evidence of the UAE. Journal of Islamic Accounting and Business Research, 8(1), 2-22.

Zarrouk, H., Galloway, L., Sherif, M., Elkaroui, E., \& Al Mulla, A. (2020). Entrepreneurial Orientation in Small Firms: A Qualitative Exploration in the Context of an Emerging Economy. In: S. Paresha, J. Gibb, M. Akoorie \& J. M. Scott (Ed.), Research Handbook on Entrepreneurship in Emerging Economies: A Contextualized Approach. Edward Elgar Publishing.

Zelger, J., \& Oberprantacher, A. (2002). Processing of Verbal Data and Knowledge Representation by GABEK ${ }^{\circledR}-$ WinRelan $\AA$. Forum Qualitative Research, 3(2), Art. 27.

Zelger, J., Raich, M., Abfalter, D., \& Müller, J. (2011). GABEK® - Theory and Application in Management Studies. EURAM, Tallinn. 


\section{End Notes}

'Innovativeness reflects the firm's tendency to support new ideas, novelty, experimentation, and creativity in introducing new products and services or developing new technological processes (Lumpkin \& Dess, 1996). Risk-taking described as "the degree to which managers are willing to make large and risky resource commitments-i.e., those which have a reasonable chance of costly failures" (Miller \& Friesen, 1978, p. 923). Proactiveness is "initiative by anticipating and pursuing new opportunities and participating in emerging markets also has become associated with entrepreneurship" (Lumpkin \& Dess, 1996, p. 146). Competitive aggressiveness is defined as " a firm's propensity to directly and intensely challenge its competitors to achieve entry or improve position, that is, to outperform industry rivals in the marketplace" (Lumpkin \& Dess, 1996, p. 148). Autonomy means individuals or teams' ability to develop ideas and carry them through to completion (Lumpkin \& Dess, 1996).

${ }^{2}$ GABEK-toolset ("GAnzheitliche BEwältigung von Komplexität"Holistic Processing of Linguistic Complexity (C) Josef ZELGER, Innsbruck) is a software used to analyze the qualitative data by developing networks, causalities, and relevancies from linguistic data. For more details, see Zelger and Oberprantacher (2002), and Zelger et al. (2011). The GABEK ${ }^{\circledR}$ technique's main strength is grounded in its accuracy generated by a rule-based framework: defining text units and criteria, basic linguistic coding, assessment of expressions (associations), and the connections of these (causalities). It also takes the qualitative and quantitative nature of textual data into account. 